\title{
Perancangan Ulang Formulir Rawat Jalan Untuk Mendukung Praktik Di Laboratorium RMIK Unjaya
}

\author{
Kori Puspita Ningsih ${ }^{1}$, Kuswanto Hardjo ${ }^{2}$ \\ ${ }^{1,2}$ Health Faculty, Universitas Jenderal Achmad Yani Yogyakarta, Indonesia
}

\section{Article Info}

Article history:

Received Jan 12, 2021

Revised Feb 08, 2021

Accepted Feb 17, 2021

\section{Keywords:}

Design

Form

Outpatient

\begin{abstract}
ABSTRAK
RMIK (D-3) Study Program Laboratory, Faculty of Health, Jenderal Achmad Yani University Yogyakarta (Unjaya) has an outpatient form. Currently, the form format is still minimal, it does not describe the integrated medical record documentation format. This research uses descriptive method, with a case study approach. The subjects of this research were the Head of the RMIK Study Program (D-3), the Head of the Laboratory, lecturers and laboratory staff of the RMIK Study Program (D-3), Faculty of Health, Jenderal Achmad Yani University Yogyakarta. Triangulation informants in this study were senior medical record practitioners in Yogyakarta City Hospital Type B. Researchers conducted a preliminary study and literature study to identify problems. Furthermore, data analysis was carried out to identify the need for redesigning the form design based on physical, anatomical and content aspects. The results of the analysis were used as the basis for the outpatient form redesign. There are 2 proposals for outpatient medical record form redesign. The selection of the design and form material was carried out by discussing with the triangulation informant, improving the design according to the input from the triangulation informant to get the final design of the outpatient form design. The results of the analysis on the physical, anatomical and content aspects show that it is necessary to redesign the form on the anatomical and content aspects by removing the registration number, class / room, occupation, adding allergy history, disease history, pain assessment and ICD code, and restructuring medical record documentation. integrated with the SOAP format.
\end{abstract}

\section{Corresponding Author:}

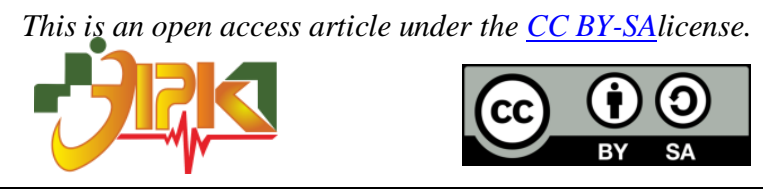

Kori Puspita Ningsih,

Health Faculty,

Universitas Jenderal Achmad Yani Yogyakarta,

Jl. Brawijaya, Ringeroad Barat, Ambarketawang, Gamping, Sleman-Daerah Istimewa Yogyakarta.

Email: puspitakori@mail.com

\section{PENDAHULUAN}

Prodi RMIK (D-3) Fakultas Kesehatan Universitas Jenderal Achmad Yani Yogyakarta melaksanakan kegiatan pendidikan yang menghasilkan lulusan Ahli Madya Kesehatan (A.Md.Kes), dimana dalam menjalankan tugas pelayanan kesehatan satu diantaranya sebagai Koordinator Unit Kerja Rekam Medis dan Informasi Kesehatan [1]. Dalam upaya menghasilkan lulusan yang kompeten, maka Prodi RMIK (D-3) Fakultas Kesehatan 
Universitas Jenderal Achmad Yani Yogyakarta menyediakan pelayanan laboratorium Manajemen Informasi Kesehatan (MIK) untuk mendukung proses pembelajaran. Dalam penyelenggaraan pendidikan tenaga perekam medis harus tersedia bahan praktik satu diantaranya berkas rekam medis [2]. Saat ini laboratorium Prodi RMIK (D-3) Fakultas Kesehatan Universitas Jenderal Achmad Yani Yogyakarta menggunakan bahan praktik berkas rekam medis.

Rekam medis digunakan dalam manajemen dan perencanaan fasilitas dan layanan perawatan kesehatan, untuk penelitian medis dan statistik kesehatan [3]. Selain itu rekam medis juga merupakan sarana untuk informasi utama atau pendokumentasian data di sarana pelayanan kesehatan [4]. Formulir merupakan alat yang digunakan dalam melakukan proses pencatatan dan pengolahan data rekam medis pasien. Untuk mendapatkan data rekam medis yang bermutu tersebut, aspek desain formulir yang baik perlu diterapkan dalam formulir rekam medis [5].

Berdasarkan pengambilan data awal diketahui bahwa laboratorium Prodi RMIK (D-3) Fakultas Kesehatan Universitas Jenderal Achmad Yani Yogyakarta (Unjaya) memiliki formulir rawat jalan untuk klinik umum yang digunakan mendukung praktikum. Namun, saat ini format formulir masih minimal, belum menggambarkan format dokumentasi rekam medis yang terintegrasi. Pentingnya pencatatan pada rekam medis tersebut juga diperkuat pada standar AP.1 bahwa asassmen yang efektif yang menghasilkan keputusan tentang tindakan yang segera dan berkelanjutanyang dibutuhkan untuk tindakan darurat, asuhan terencana bahkan jika kondisi pasien berubah, baik rawat jalan, maupun gawat darurat [6]. Mengingat pentingnya rekam medis sebagai bahan praktik rekam medis [2], khususnya formulir rawat jalan pada pencatatan hasil pemeriksaan pasien [7], maka sebagai solusi permasalahan tersebut perlu dilakukan perancangan ulang formulir formulir rawat jalan untuk mendukung praktik Laboratorium Rekam Medis Universitas Jenderal Achmad Yani Yogyakarta.

\section{METODE PENELITIAN}

Penelitian ini menggunakan metode deskriptif, dengan pendekatan studi kasus. Lokasi penelitian ini di Laboratorium Rekam Medis dan Informasi Kesehatan (RMIK) Fakultas Kesehatan Universitas Jenderal Achmad Yani Yogyakarta (Unjaya). Subjek penelitian ini adalah Ketua Prodi RMIK (D-3), Kepala Laboratorium, dosen dan staf laboratorium Prodi RMIK (D-3) Fakultas Kesehatan Universitas Jenderal Achmad Yani Yogyakarta. Informan triangulasi pada penelitian ini adalah praktisi senior rekam medis di RSUD Tipe B Kota Yogyakarta. Objek pada penelitian ini adalah formulir pendaftaran dan formulir rawat jalan. Peneliti melakukan studi pendahuluan dan studi pustaka untuk mengidentifikasi masalah. Selanjutnya analisis data dilakukan identifikasi kebutuhan perancangan ulang desain formulir berdasarkan aspek fisik, anatomi dan isi. Hasil analisis tersebut digunakan sebagai dasar untuk perancangan ulang formulir rawat jalan. Terdapat 2 usulan perancangan ulang formulir rekam medis rawat jalan. Pemilihan desain dan bahan formulir dilakukan dengan diskusi bersama informan triangulasi, perbaikan desain sesuai masukan dari informan triangulasi untuk mendapatkan desain akhir dari perancangan formulir rawat jalan.

\section{HASIL DAN PEMBAHASAN}

\subsection{Hasil}

\section{Fungsi Formulir Rawat Jalan}

Formulir rawat jalan di Labratorium RMIK Unjaya berfungsi sebagai bahan praktik skill laboratorium mahasiswa Program Studi Rekam Medis dan Informasi Kesehatan (D-3) pada kegiatan praktik pendaftaran pasien rawat jalan yang dilakukan dengan metode role play untuk memenuhi capaian pembelajaran Manajemen Rekam Medis dan praktik desain 
formulir rekam medis yang dilakukan dengan metode studi kasus untuk memenuhi capaian pembelajaran Desain Manajamen Formulir. Formulir rekam medis merupakan satu diantara bahan praktik yang diperlukan di laboratorium rekam medis [2]. Formulir yang digunakan unuk pelayanan klinik umum, yang mendokumentasikan identitas sosial pasien, data medis hingga autentifikasi dokter dengan tujuan untuk memudahkan dan mempercepat pelayanan dalam upaya menjaga kesinambungan riwayat kesehatan pasien adalah fungsi dari desain formulir rekam medis rawat jalan [8].

\section{Analisis Formulir Rawat Jalan}

Peneliti melakukan analisis formulir rawat jalan ditinjau dari aspek fisik, anotomi dan isi [9], [10]. Berikut desain formulir rawat yang digunakan di laboratorium RMIK Unjaya:

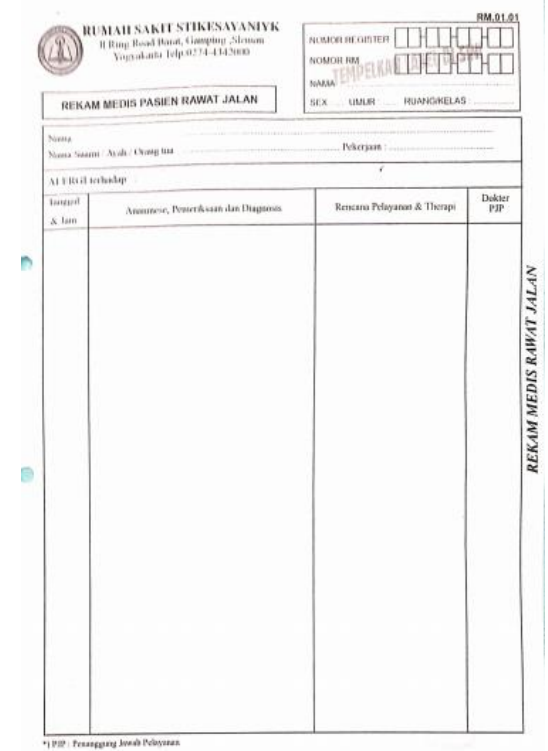

\section{Gambar 1. Formulir rawat jalan yang digunakan saat ini digunakan di Lab RMIK} Unjaya

Berikut ini adalah aspek fisik, aspek anatomi, dan aspek isi formulir rawat jalan yang saat ini digunakan di laboratorium RMIK Unjaya adalah:

a. Aspek Fisik

Analisis desain formulir rekam medis rawat jalan dari aspek fisik meliputi bahan, bentuk, ukuran dan warna [9], [11]. Berikut hasil analisis formulir pada aspek fisik (tabel 1):

Tabel 1. Aspek Fisik Formulir Rawat Jalan

\begin{tabular}{lll}
\hline No & Aspek Fisik & \multicolumn{1}{c}{ Hasil } \\
\hline 1 & Bahan & Kertas HVS 70 gram \\
\hline 2 & Bentuk & Berbentuk potrait dengan lebar 21,6 cm dan panjang $35,6 \mathrm{~cm}$ \\
\hline 3 & Ukuran & HVS \\
\hline 4 & Warna & Putih \\
\hline
\end{tabular}

Formulir rawat jalan di Laboratorium RMIK Unjaya berbahan kertas HVS berat 70 gram. Dapat disampaikan bahan dari formulir tersebut tersebut cukup tebal dan tidak mudah rusak dan sobek [9]. Namun dari penelitian lain menunjukkan bahwa desain formulir yang berbahan kertas HVS dengan berat 70 gram dapat menyebabkan formulir menjadi lebih mudah sobek [5]. Pertimbangan lain dalam pemilihan bahan formulir adalah dari sifat kertas yang berkaitan dengan permanency, durability, mutu penulisan kertas, keterbacaan dan pembuatan mikrofilm. Sifat kertas permanency ini berkaitan dengan lama waktu simpan kertas, sedangkan durability berkaitan dengan kemampuan dalam 
pengelelolaan kertas secara kontinue. Selain itu, mutu kualitas kertas juga akan mempengaruhi kemampuan seseorang untuk menulis dengan cepat dan rata serta kemampuan kertas untuk menerima tinta dari alat percetakan [11].

Formulir rawat jalan di Laboratorium RMIK Unjaya berbentuk potrait dengan lebar 21,6 cm dan panjang 35,6 cm, ukuran HVS berwarna putih. Berdasarkan penelitian sejenis yang dilakukan oleh Endah Puspitasari et all dengan judul "Perancangan Desain Formulir Rekam Medis Pasien Rawat Jalan Poliklinik Umum Di Puskesmas Kauman Kabupaten Ponorogo" menunjukkan desain formulir rawat jalan dengan kertas HVS berat 80 gram, ukuran lebar $22 \mathrm{~cm}$ dan panjang $34 \mathrm{~cm}$ dengan kertas berwarna merah muda untuk pasien perempuan dan kertas berwarna biru untuk pasien laki-laki [8]. Sedangkan pada penelitian yang dilakukan oleh Subinarto et all dengan judul "Analisis Desain Formulir Ringkasan Masuk dan Keluar Rawat Inap" juga menjelaskan bahwa perancangan desain formulir ringkasan masuk dan keluar menggunakan ukuran HVS berbentuk potrait [5].

\section{b. Aspek Anatomi}

Analisis aspek anatomi pada formulir rawat jalan ditinjau berdasarkan aspek heading, introduction, instruction, body, font, ruler dan border. Berikut hasil analisis formulir rawat jalan pada aspek anatomi (tabel 2):

Tabel 2. Aspek Anatomi Formulir Rawat Jalan

\begin{tabular}{|c|c|c|}
\hline No & $\begin{array}{c}\text { Aspek } \\
\text { Anatomi }\end{array}$ & Hasil \\
\hline 1 & Heading & $\begin{array}{l}\text { Terdapat logo, nama, alamat, dan nomor telepon akan tetapi } \\
\text { belum sesuai identitas Unjaya terkini }\end{array}$ \\
\hline 2 & Introduction & Terdapat judul formulir "Rekam Medis Pasien Rawat Jalan" \\
\hline 3 & Intruction & $\begin{array}{l}\text { Terdapat informasi cara pengisian identitas pasien pada bagian } \\
\text { heading formulir yang bertuliskan "mohon diisi atau ditempal } \\
\text { stiker jika ada" }\end{array}$ \\
\hline & Body & $\begin{array}{l}\text { Terdapat rule untuk mempermudah pengguna mengisi formulir } \\
\text { sesuai batas kewenangan masing-masing. Terdapat item data } \\
\text { yang bias yaitu pekerjaan yang teletak di sebelah kanan nama } \\
\text { suami/ayah/orang tua. }\end{array}$ \\
\hline 5 & Font & $\begin{array}{l}\text { Font yang digunakan menggunakan Times New Roman ukuran } \\
14 \text { untuk identitas formulir, Times New Roman ukuran } 12 \\
\text { untuk isi formulir dan Arial ukuran } 14 \text { untuk judul formulir. } \\
\text { Terdapat beberapa font yang diberi tanda Bold sebagai } \\
\text { penegasan dari informasi pada formulir. }\end{array}$ \\
\hline & Ruler & $\begin{array}{l}\text { Terdapat ruler pada formulir untuk membatasi heading dan } \\
\text { body formulir }\end{array}$ \\
\hline 7 & Border & Terdapat border dalam formulir \\
\hline \multicolumn{3}{|c|}{$\begin{array}{l}\text { Heading formulir rawat jalan yang digunakan di laboratorium RMIK Unajya } \\
\text { nginformasikan identitas formulir yang bertuliskan "Rumah Sakit Stikes Ayani YK" } \\
\text { logo Stikes Jenderal Achmad Yani Yogyakarta. Hal ini tentunya belum sesuai dengan } \\
\text { na dan logo terkini dari institusi yang saat ini bernama Universitas Jenderal Achmad } \\
\text { ni Yogyakarta, atau umumnya disebut dengan "Unjaya". Berdasarkan hasil diskusi } \\
\text { gan Ketua Prodi RMIK, kepala laboratorium, dosen dan staf lab RMIK diketahui } \\
\text { Iwa lab RMIK Unjaya memiliki kebutuhan untuk menyesuaikan identitas formulir pada } \\
\text { n logo dan nama Universitas Jenderal Achmad Yani Yogyakarta sesuai dengan kondisi } \\
\text { kini. Adanya ketidaksesuaian identitas formulir tersebut dengan kondisi terkini } \\
\text { dampak identitas formulir tidak akurat [12]. }\end{array}$} \\
\hline
\end{tabular}


Dari aspek introduction terdapat judul formulir "Rekam Medis Pasien Rawat Jalan". Hal ini sudah sesuai dengan fungsi formulir sebagai dokumen yang mendokumentasikam hasil pemeriksaan pasien rawat jalan. Selanjutya pada aspek introduction dan intruction diperlukan untuk menjelaskan tujuan dari formulir [13]. Identifikasi dan instruksi umum terlrtak di bagian atas formulir, dibuat secara singkat dan apabila intruksi tersbut cukup panjang, maka dapat ditempatkan pada buku atau lembaran [14]. Pada aspek intruction di formulir rekam medis rawat jalan Lab RMIK Unjaya terdapat informasi cara pengisian identitas pasien yang terletak di bagian heading formulir yang bertuliskan "mohon diisi atau ditempal stiker jika ada". Dengan adanya intruksi tersebut diharapkan petugas rekam medis dapat melengkapi identitas pasien dengan tulisan tangan maupun stiker. Identitas pasien pada kepala (heading) formulir rawat jalan di laboratorium Unjaya meliputi nomor registrasi, nomor RM, nama, sex, umur, ruang/kelas, pekerjaan. Untuk item data nama ditulis 2 kali yaitu dibagian kepala formulir dan dibagian introduction. Informasi yang dublikat tersebut tentunya kurang efektif. Selain itu, informasi identitas pasien juga kurang optimal untuk mendukung identifikasi pasien, karena nomor registrasi dan ruang/kelas akan berubah setiap pasien berkunjung. Menurut SNARS Edisi-1 standar SKP 1 bahwa identifikasi pasien minimal terdiri dari nomor rekam medis, nama pasien, tanggal lahir atau jenis kelamin. Identifikasi pasien tersebut diperlukan untuk mendukung keselamatan pasien [6].

Aspek body pada formulir rawat jalan di laboratorium Unjaya menunjukkan bahwa terdapat rule untuk mempermudah pengguna mengisi formulir sesuai batas kewenangan masing-masing. Terdapat item data yang bias yaitu pekerjaan yang teletak di sebelah kanan nama suami/ayah/orang tua. Hal ini berpotensi terjadi ketidakakuratan pengisian data pekerjaan yang dimaksudkan untuk pekerjaan pasien tetapi justru diisi pekerjaan suami/ayah/orang tua karena letaknya yang berada di sebelah kanan nama suami/ayah/orang tua.

Font yang digunakan menggunakan Times New Roman ukuran 14 untuk identitas formulir, Times New Roman ukuran 12 untuk isi formulir dan Arial ukuran 14 untuk judul formulir. Terdapat beberapa font yang diberi tanda Bold sebagai penegasan dari informasi pada formulir [9]. Font menunjukkan jenis huruf yang digunakan. Oleh karena itu,dalam melakukan desain formulir perlu diperhatikan ukuran, penebalan huruf, huruf miring, dan lain sebagainya [13].

Selanjutnya pada formulir rawat jalan sudah terdapat ruler yang digunakan untuk membatasi kepala dan badan formulir. Untuk menjelaskan dan menekankan item data pada formulir diperlukan ruler yang dibuat langsung tanpa menggunakan garis putus-putus [10]. Rules juga dapat ditunjukkan melalui garis vertikal dan horisontal yang bermanfaat dalam pembagian formulir menjadi bagian-bagian yang mengarahkan pada entry lokasi [13].

\section{c. Aspek Isi}

Aspek isi formulir menjelaskan kelengkapan item pada formulir. Aspek isi formulir meliputi kelengkapan item, terminologi, singkatan, dan simbol [5]. Pada analisis aspek isi, kelengkapan item ditinjau dari identitas institusi, identitas pasien, identitas penanggung jawab, tanggal dan jam, informasi medis, autentifikasi dan singkatan. Formulir rawat jalan minimal berisi tentang identitas pasien, tanggal dan waktu, hasil anamnesis, mencakup sekurang kurangnya keluhan dan riwayat penyakit, hasil pemeriksaan fisik dan penunjang medis, hasil pemeriksaan fisik dan penunjang medis, diagnosis, rencana penatalaksanaan, pengobatan dan atau tindakan, pelayanan lain yang telah diberikan kepada pasien, dan untuk pasien kasus gigi dilengkapi dengan odontogram klinik, persetujuan tindakan bila diperlukan [15]. Berikut hasil analisis aspek isi pada formulir rawat jalan (tabel 3): 
Tabel 3. Aspek Isi Formulir Rawat Jalan

\begin{tabular}{cll}
\hline No & Aspek Isi & \multicolumn{4}{c}{ Hasil } \\
\hline 1 & Identitas institusi & $\begin{array}{l}\text { Tersedia identitas institusi yang terletak di bagian } \\
\text { heading (kepala) formulir, akan tetapi belum sesuai } \\
\text { identitas Unjaya terkini. }\end{array}$ \\
\hline 2 & Identitas Pasien & $\begin{array}{l}\text { Nomor registrasi, nomor RM, nama, sex, umur, } \\
\text { ruang/kelas dan pekerjaan, Nama ditulis 2 kali dibagian } \\
\text { kepala formulir dan introduction. }\end{array}$ \\
\hline 3 & Identitas & Nama suami/ayah/orang tua \\
& Penanggungjawab & Terdapat item tanggal dan jam \\
\hline 4 & Tanggal dan jam & Terdapat item anamnase, pemeriksaan dan diagnosa pada \\
& Informasi medis & $\begin{array}{l}\text { satu kolom yang sama. Item rencana pelayanan dan terapi } \\
\text { juga terdapat pada satu kolom yang sama pula. Item } \\
\text { alergi terletak dibawah introduction. }\end{array}$ \\
\hline 6 & Autentifikasi & $\begin{array}{l}\text { Terdapat item dokter PJP (tanpa ada penjelasan item } \\
\text { tersebut untuk nama atau tanda tangan dokter PJP) }\end{array}$ \\
\hline 7 & Singkatan & $\begin{array}{l}\text { Terdapat penggunaan singkatan PJP yang memiliki } \\
\text { makna Penanggung Jawab Pelayanan. }\end{array}$ \\
\hline
\end{tabular}

Berdasarkan aspek isi dapat disampaikan bahwa kelengkapan item formulir yang perlu dianalisis Komponen tersebut sudah terdapat pada formulir general consent pasien rawat inap di lab RMIK Universitas Jenderal Achmad Yani Yogyakarta. Pada indentitas sarana pelayanan kesehatan perlu dilakukan redesain untuk mengupdate identitas nama dan logo rumah sakit. Selanjutnya untuk identitas pasien belum mencakup minimal 2 dari 3 komponen yaitu Nama, Nomor rekam medis, Tanggal lahir, karena belum terdapat item tanggal lahir pasien [6]. Mengacu pada Permenkes 269/Menkes/Per/III/2008 bahwa identitas penanggung jawab tidak termasuk dalam isi minimal rekam medis rawat jalan.

Selanjutnya untuk kelengkapan item tanggal dan jam sudah sesuai dengan kebutuhan, sedangkan untuk informasi medis sudah terdapat item anamnase, pemeriksaan dan diagnosa pada satu kolom yang sama. Item rencana pelayanan dan terapi juga terdapat pada satu kolom yang sama pula. Item alergi terletak dibawah introduction.

Pada autentifikasi formulir rawat jalan di laboratorium RMIK Unajaya hanya terdapat item dokter PJP, tetapi tidak ada penjelasan item tersebut untuk nama atau tanda tangan dokter PJP. Autentifikasi pada formulir memuat nama dan tanda tangan penulis [16]. Terdapat 1 singkatan pada pada formulir rawat jalan yaitu PJP, yang menjelaskan Penanggung Jawab Pelayanan. Menurut standar MIRM.12 elemen penilaian ke-5 disampaikan bahwa rumah sakit diminta memiliki daftar singkatan yang diperkenankan dan dilarang [6].

\subsection{Pembahasan}

\section{Perancangan Ulang Formulir Rawat Jalan}

Berdasarkan hasil analisis desain formulir rawat jalan di laboratorium RMIK Unjaya dari aspek fisik, anatomi dan isi dapat disimpulkan bahwa perlu dilakukan perancangan ulang formulir rawat jalan untuk memenuhi kebutuhan pengguna.Hal ini tentunya juga mendukug capaian pembelajaran Prodi RMIK (D-3) Fakultas Kesehatan Unjaya yaitu mampu mengikuti perkembangan IPTEK dibidang rekam medis untuk menghadapi persaingan global (P04) [1]. Penelitian sejenis juga dilakukan oleh Heri Hernawan et all dengan judul "Analisis Desain Map Rekam Medis" bahwa dalam mendukung capaian pembelajaran mahasiswa untuk mampu perkembangan IPTEK dibidang rekam medis dalam menghadapi persaingan global (P04) perlu dilakukan perancangan ulang map rekam medis [9]. 
Selanjutnya berdasarkan hasil diskusi dengan Ketua Prodi RMIK, kepala laboratorium, dosen dan staf lab RMIK disepakati item nomor registrasi, kelas/ruah dan pekerjaan dihilangkan. Hal ini dikarenakan pekerjaan sudah tertuang pada formulir pendaftaran dibagian general consent pasien rawat jalan, sehingga disepakati bahwa untuk kebutuhan data penanggung jawab pasien rawat jalan cukup menggunakan formulir pendaftaran dengan mengoptimalkan bagian general consent. Formulir general consent merupakan salah satu formulir yang wajib dimintakan persetujuan karena isinya menyangkut hak dan kewajiban pasien serta pelayanan kesehatan yang akan dilakukan kepada pasien berterkaitan dengan proses pemeriksaan, perawatan, dan pengobatan [17]. Sedangkan pada Standar HPK 5 juga disampaikan bahwa formulir general consent dimintakan pada saat pasien melakukan registrasi rawat jalan dan setiap kali pasien rawat inap. Rumah sakit memiliki dokumentasi dalam rekam medis tentang general consent [6].

Informasi identitas pasien yang meliputi nomor registrasi dan ruang/kelas akan berubah setiap pasien berkunjung. Nomor registrasi tidak perlu dicantumkan di identits pasien. Hal ini mengacu kepada Formulir rawat jalan ini hanya digunakan untuk pasien rawat jalan, sehingga informasi ruang/kelas tidak perlu dicantumkan pada bagian identitas pasien. Selanjutnya Untuk mendukung kebutuhan pendokumentasia terintegrasi pada formulir rawat jalan dengan format SOAP. Dokumentasi rekam medis terintegrasi tersebut ditekankan pula pada standar AP.1 bahwa asassmen yang efektif yang menghasilkan keputusan tentang tindakan yang segera dan berkelanjutan yang dibutuhkan untuk tindakan darurat, asuhan terencana bahkan jika kondisi pasien berubah, baik rawat jalan, maupun gawat darurat dan unit pelayanan lainnya. Adapun metode assesmen menggunakan metode IAR, dimana huruf I untuk menjelaskan proses pengumpulan data dan informasi. Pada SOAP adalah S-Subyektif dan O-Obyektif. Huruf A untuk menejelaskan proses analisis data dan informasi. Pada SOAP adalah A-Assasmen. Huruf R untuk menjelaskan proses rencana, yaitu menyusun solusi untuk mengatasi atau memperbaiki pemasalahan atau kelaianan kesehatan pasien. Pada SOAP adalah P-Plan. Dimana isi minimal assasmen awal salah satunya minimal adalah riwayar alergi, riwayat penyakit dan assasmen nyeri [6]. Berdasarkan hasil diskusi pula diketahui bahwa pada desain formulir rekam medis rawat jalan belum terdapat kolom kode ICD. Klasifikasi Diagnosis adalah penyeragaman penyakit-penyakit dan prosedur-prosedur yang sejenis ke dalam suatu grup nomor kode penyakit dan tindakan yang sejenis. International Statistical Classification of Diseases and Related HealthProblem (ICD) merupakan suatu sistem klasifikasi yang komprehensif dan diakui secara internasional. ICD-10 digunakan sebagai pedoman untuk merekam dan memberi kode penyaki, dan digunakan pula untuk analisis, intepretasi, serta membandingkan data morbiditas dan mortalitas dari negara yang berbeda atau antar wilayah yang berbeda, sedangkan ICD-9 CM digunakan sebagai pedoman klsifiksi operasi dan tindakan [18] [19] .

Berikut hasil perancangan ulang formulir rekam medis rawat jalan yang sudah disepakati oleh informasn triangulasi: 


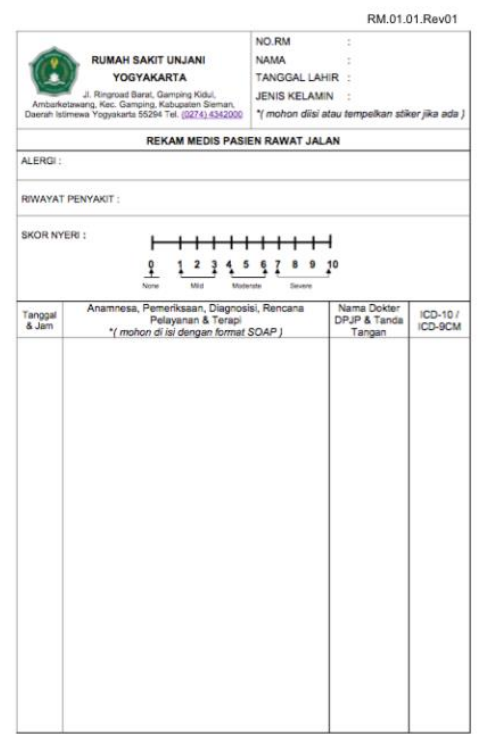

Gambar 2. Hasil Perancangan Ulang Formulir Rawat jalan

\section{KESIMPULAN}

Formulir rekam medis rawat jalan di Laboratorium RMIK Unjaya digunakan sebagai bahan praktik pendaftaran dan desain formulir rekam medis oleh mahasiswa Program Studi RMIK Unjaya dengan metode roleplay. Hasil analisis pada aspek fisik, anatomi dan isi menunjukkan perlu dilakukan perancangan ulangformulir pada aspek anatomi dan isi.

\section{REFERENCES}

[1] Prodi RMIK, Surat Keputusan Nomor: Skep 054/FKES/VIII/ 2019 tentang Kurikulum Pendidikan Program Studi Perekam dan Infokes (D-3) Fakultas Kesehatan Universitas Jenderal Achmad Yani Yogyakarta. 2019.

[2] Kemenkes, Surat Keputusan Menteri Kesehatan Republik Indonesia No. HK.03.05/IV/14354.1/2010 tanggal 31 Desember 2010 tentang Standar Laboratorium Pendidikan Tenaga Kesehatan. 2010.

[3] WHO, Medical Records Manual : A Guide for Developing Countries. Geneva: WHO Library Cataloguing in Publication Data, 2017.

[4] G. R. Hatta, Pedoman Manajemen Informasi Kesehatan di Sarana Pelayanan Kesehatan. Jakarta: Universitas Indonesia, 2017.

[5] Subinarto, "Analisis Desain Formulir Ringkasan Masuk dan Keluar Rawat Inap Poltekkes Kemenkes Semarang RS Palang Biru Kutoarjo," J. Rekam Medis dan Inf. Kesehat., vol. 1, no. 2, pp. 76-81, 2018, doi: http://dx.doi.org/10.31983jrmik.vli2.3850.

[6] KARS, "Standar Nasional Akreditasi Rumah Sakit Edisi 1," 1st ed., Jakarta: KARS, 2017, pp. 1-421.

[7] Kemenkes, Peraturan Menteri Kesehatan RI Nomor 269/Menkes/Per/III/2008 tentang Rekam Medis. 2008.

[8] Endah Puspitasari. etall, "Perancangan Desain Formulir Rekam Medis Pasien Rawat Jalan Poliklinik Umum Di Puskesmas Kauman Kabupaten Ponorogo," Glob. Heal. Sci., vol. 2, no. 2, pp. 87-90, 2017, doi: 10.1016/j.cbpa.2012.10.010.

[9] Heri Hernawan \& Kori Puspita Ningsih, "Analisis Desain Map Rekam Medis," $J$. Rekam Medis dan Inf. Kesehat., vol. 3, no. 2, pp. 99-105, 2020.

[10] K. Nissaa, T. Lestar, and S. Mulyono, "Pengembangan Desain Map Rekam Medis (Folder) dengan Kode Warna Di RSUD Pandan Arang Boyolali,” no. 2, p. 158, 2014. 
[11] F. Hikmah, R. A. W. Wijayanti, and M. J. C. Laksono, "Desain Formulir Asesmen Nyeri Dalam Berkas Rekam Medis di Rumah Sakit Daerah Balung Jember Tahun 2016," J. Kesehat., vol. 5, no. 3, pp. 138-148, 2019, doi: 10.25047/j-kes.v5i3.28.

[12] M. Abdelhak, Health Information: Management of a Strategic Resource. Missouri: Saunders Elsevier, 2016.

[13] E. Rustiyanto, Manajemen Filing Dokumen Rekam Medis dan Informasi Kesehatan. Yogyakarta: Politeknik Kesehatan Permata Indonesia, 2011.

[14] Puspitasari;etall, "Perancangan Desain Formulir Rekam Medis Pasien Rawat Jalan Poliklinik Umum Di Puskesmas Kauman Kabupaten Ponorogo," Glob. Heal. Sci., vol. 2, no. 2, pp. 87-90, 2017, doi: 10.1016/j.cbpa.2012.10.010.

[15] Kemenkes RI, "Pemenkes 269/PER/III/2008 tentang Rekam Medis," Kemenkes RI. pp. 1-7, 2008.

[16] L. Herfiyanti, "Kelengkapan Informed Consent Tindakan Bedah Menunjang Akreditasi Jci Standar Hpk 6 Pasien Orthopedi," J. Manaj. Inf. Kesehat. Indones., vol. 3, no. 2, pp. 81-88, 2015, doi: 10.33560/.v3i2.89.

[17] N. Yulia and D. Nurazizah, "Tinjauan Penjelasan General Consent Di Pendaftaran Rawat Inap Rs Medika Permata Hijau," Pros. Semin. Nasinal rekam Medis dan Inf. Kesehat. "Penguatan Pendidik. Tenaga Kesehat. di Era Ind. 4.0,” pp. 17-22.

[18] H. Hernawan, K. P. Ningsih, and W. Winarsih, "Ketepatan Kode Diagnosis Sistem Sirkulasi di Klinik Jantung RSUD Wates," JKESvo, vol. 2, no. 1, p. 148, 2017, doi: 10.22146/jkesvo.30328.

[19] WHO, Revision, The Tenth Classification, International Statistical Problems, Related Health Classification, vol. 1. 2013.

\section{BIOGRAPHIES OF AUTHORS}

\begin{tabular}{|l|l|}
\hline Kori Puspita Ningsih. Dosen Program Studi Rekam Medis dan Informasi Kesehatan \\
(D-3) Fakultas Kesehatan, Universitas Jenderal Achmad Yani Yogyakarta.
\end{tabular}

